\title{
Fungi detected in trunk of stone fruits in the Czech Republic
}

\author{
${ }^{1}$ Jakub Pečenka $-{ }^{1}$ Eliška Peňázová $-{ }^{2}$ Dorota Tekielska $-{ }^{3}$ Ivo Ondrášek $-{ }^{3}$ Tomáš Nečas $-{ }^{1}$ Aleš Eichmeier \\ ${ }^{1}$ Mendel University Faculty of Hoticulture, \\ Department of Genetics, Lednice, Czech Republic \\ ${ }^{2}$ University of Agriculture, Faculty of Biotechnology and Horticulture, \\ Department of Plant Protection, Krakow, Poland \\ ${ }^{3}$ Mendel University Faculty of Hoticulture, \\ Department of Fruit Growing, Lednice, Czech Republic \\ jakubpecenka@mendelu.cz
}

\section{SUMMARY}

This study was focused on detection of the spectrum of fungi in the wood of stone fruits using molecular genetic methods. Samples were obtained from apricots, plums and sweet cherry trees from region of Moravia, one sample was obtained from Myjava (Slovakia). Segments of symptomatic wood were obtained from dying stone fruit trees with very significant symptoms. This study describes detection of the fungi in the wood of 11 trees in general in 5 localities. The cultivation of the fungi from symptomatic wood and sequencing of ITS was carried out. Eleven fungal genera were determined in the stone fruits wood, particularly Irpex lacteus, Fomes fomentarius, Neofabraea corticola, Calosphaeria pulchella, Cytospora leucostoma, Phellinus tuberculosus, Stereum hirsutum, Collophora sp., Pithomyces chartarum, Aureobasidium pullulans, Fusarium sp. The results of this study demonstrate that the reason of declining of stone fruit trees in Moravia is caused probably by trunk pathogens.

Keywords: stone fruit, fungal trunk pathogens, detection, ITS, Calosphaeria, Cytospora, Collophora genera

\section{INTRODUCTION}

Diseases of fruit trees have a negative effect on their yield and viability in growing regions around the world (Gramaje et al. 2010, 2012; Bertsch et al. 2013). Causal pathogens of premature death include viruses, especially PPV (Plum pox virus), bacteria (Pseudomonas syringae pv. Syringae) or still world spreading $X y$ lella fastidiosa, a phytoplasma 'Candidatus Phytoplasma prunorum' or, 'Candidatus Phytoplasma mali', 'Candidatus Phytoplasma pyri' and last but not least fungal trunk disease (TD) pathogens. TD pathogens are agents of necrotic rot which are characterized by the creation of dead and typically coloured tissues. TDs fungal species are complex of taxonomically unrelated fungi from Botryosphaeriaceae and Diatrypaceae family and species of genera Cadophora, Campylocarpon, Collophora, Cylindrocarpon, Cylindrocladiella, Dactylonectria, Ilyonectria, Phaeoacremonium and Phaeomoniella and fungi of Basidiomycetes.

The history of fruit growing in the Czech Republic has a long tradition. However there was a big decline of fruit growing after Battle of Bílá Hora in 1620 . Expansion of fruit growing came after reforms of Josef II and the establishment of associations of fruit breeders (Becha 2013). Stone fruits grown traditionally in the Czech Republic include the plums, the cherries, and in the warmer areas also the apricots. Currently the level of cultivation is not satisfying. From 1950 till now stone fruit production areas in the Czech Republic are decreased rather and/or stagnate. The worse situation is in peach orchards where the area was decreased by $47 \%$. Nowadays stone fruit growers leave this activity in the Czech Republic.

One of the reasons are an important losses of trees seven years after planation. Plantation areas of sweet and sour cherries are stagnating however these plantations are going to be old. On the other hand the production areas of plums increased almost five times (Buchrová 2015). However, the yield and quality of the fruit market is lagging behind compared with other countries but nutritional value and taste remain comparable in the Czech Republic.

There are several causes of these conditions including deficiencies in the selection of suitable areas for growing fruits as not suitable agronomic technologies, increasing investment costs for the establishment and maintenance of the production areas and ultimately lower yields and lower fruit quality due to the effect of abiotic and biotic factors (Becha 2013). Maintaining good health of stone fruits orchards becomes very difficult because of the significant proportion of aged plantations, which is a prerequisite for a higher incidence of diseases and pests. These areas may serve as a niche of potential source for the spread of the diseases into productive plantations of stone fruits (www.ovocnarska unie.cz 2016).

\section{TRUNK PATHOGENS OF STONE FRUITS}

Polák et al. (2010), Nečas et al. (2014) and Žežlina et al. (2016), published the most important pathogens of stone fruits including Candidatus Phytoplasma prunorum, Plum pox virus (PPV), Xanthomonas campestris pv. pruni, Pseudomonas syringae pv. persicae and pv. morsprunorum and also trunk pathogens like Leucostoma persoonii or Valsaria insitiva. Another very important factor in stone fruit orchards are the interactions between and succession between the more recent and older fungal diseases, such as those observed between bacterial diseases and perennial canker (Žežlina et al. 2016).

Cross infection by fungal trunk pathogens has been occurred worldwide. It supports the theory that multiple hosts are affected by wide spectrum of fungal pathogens. 
Simultaneously infected host could work as sources of inoculum of trunk pathogens (Olmo et al. 2015). Crops are cultivated close to vineyards such as olives (Carlucci et al. 2013, 2014; Úrbez-Torres et al. 2013), pome fruit trees (Cloete et al. 2011) and Prunus sp. (Damm et al. 2008, 2010; Inderbitzin et al. 2010; Gramaje et al. 2012), have been considered as potential sources of inoculum for the trunk disease pathogens from which grapevines could be infected. Damm et al. (2008) and Gramaje et al. (2012) published that these hosts could serve as an additional niche of pathogen spread.

\section{DESCRIPTON OF FUNGI DETECTED IN THE WOOD OF STONE FRUITS IN CZECH REPUBLIC}

\section{Irpex lacteus}

Cosmopolitan white rot fungus typically inhabiting hardwood braches. Fruiting bodies are annual, broadly effused to effused-reflexed and sessile. Often fruiting bodies fuse laterally to make large sheets that totally cover broken or dead branches. Pore surface appears spiny because of erosion and splitting of pores, white to pale cream-colored. Pores initially angular, $2-3$ per $\mathrm{mm}$. White-rot on fallen branches and dead branches still attached to the tree (Binion et al. 2008).

\section{Fomes fomentarius}

The fungus causes decay of birches and oaks. Perennial, hard, woody, horse hoof-shaped conk with prominent zones and furrows, broadly attached to substrate. Solitary or in groups on living trees, stumps and logs. Causes a white spongy mottled heart rot of living trees, continues to fruit on dead stumps and logs. Decay first appears as a light brown discoloration with the wood remaining quite firm. Wood with advanced decay is yellow-white, soft and spongy, and frequently contains brown to black zone lines. Small radial cracks filled with yellow fungal mycelium develop, giving the decay a mottled appearance. Most common on birch but has been reported on oak (Glaeser and Smith 2010).

\section{Neofabraea corticola syn. Pezicula corticola}

The genus Neofabraea is an important pathogenic genus that representatives attack mainly apple and pear trees and cause bark diseases (anthracnose canker and perennial canker) and bull's eye rot of fruits (Pešicová 2010). N. corticola is dangerous especially for young plantations of apples and pears. This pathogen is known as an agent of bark necrosis (Verkley 1999).

\section{Calosphaeria pulchella}

Calosphaeriaceae are typical inhabitants of wood and bark of a broad spectrum of trees and shrubs worldwide, including Prunus wood (Damm et al. 2008). Branches and trunks affected by Calosphaeria pulchella has cankers and vascular necroses developed in tree limbs and branches, generally initiating from the heart wood and later spreading into the sapwood. External symptoms of disease may be unapparent throughout the early stages of infection, particularly in large diameter shoots. Older infections often appeared as wilted leaves (Trouillas et al. 2010).

\section{Cytospora leucostoma}

Cytospora leucostoma (syn. Valsa leucostoma) is an important pathogen of peaches and other stone fruits and it is limitation factor of fruit production in many areas. Symptoms include cankering of the trunk and branches, branch dieback and progressive weakening of the tree (Scorza and Pusey 1984). C. leucostoma gave evidence of xylem dysfunction as an important trigger of symptom. Affected trees during active growth secrete gum within and outside of tissues at loci of infection and display symptoms of acute and chronic water stress (Hampson and Sinclair 1973).

\section{Phellinus tuberculosus}

All taxa are parasitic and/or saprobic on wood and cause a white rot. Its fruiting bodies, often growing on wood, are resupinate, sessile, and perennial. The flesh is tough and woody or cork-like, and brown in colour (Fischer 1996, He et al. 2014). P. tuberculosus is essentially associated with Prunus sp., although it is also reported from other deciduous trees (Ghobad-Nejhad and Dai 2007).

\section{Stereum hirsutum}

Species of Stereum are easily recognized by their relatively thin fruiting bodies that are often fan shaped to paddle-shaped and their smooth spore-bearing under surface that lacks pores, gills or other supporting structures. All Stereum species cause the white sap rot and associated with the dead trees and woody debris. Several other Stereum species grow on conifers (Glaeser and Smith 2010).

\section{Collophora sp.}

Species of the genus Collophora have been reported in a list of fungal trunk pathogens isolated from Prunus sp. Collophora species were isolated from the black spots and dark brown to black streaking of the xylem tissue together with Phaeoacremonium sp. (Gramaje et al. 2012). Colonies of Collophora sp. are slow-growing, moist, white, cream or reddish colours, with sparse or lacking aerial mycelium. Conidiophores reduced to conidiogenous cells. Conidiogenous cells enteroblastic, intercalary, reduced to very short adelophialides or more often with collarettes formed directly on hyphal cells. Conidia aggregated in masses around the hyphae and on the agar surface (Damm et al. 2010).

\section{Pithomyces chartarum}

Pithomyces is a large ascomycetous genus of Pleosporales with species commonly colonizing dead leaves and stems of many different plants (Da Cunha et al. 2014). Studies in morphology of $P$. chartarum have shown it to be an extremely variable species influenced greatly by conditions such as temperature and substrate under which it is grown. Pithomyces chartarum (Berk. \& CurL), M. B. Ellis is a cosmopolitan saprophytic fungus (Dingley 1962).

\section{Aureobasidium pullulans}

Aureobasidium pullulans is a black, yeast-like fungus that is particularly known for its biotechnological significance as a producer of the biodegradable extra- 
cellular polysaccharide (EPS) pullulan (poly- $\alpha-1.6-$ maltotriose). Aureobasidium pullulans is a ubiquitous and widespread oligotrophe that can be found in environments with fluctuating water activities. It can also be found in osmotically much stressed environments, such as hypersaline waters in salterns and rocks and monuments. Due to the production of large quantities of yeast-like propagules, this fungus disperses globally (Zalar et al. 2008).

\section{Fusarium sp.}

The most of Fusarium species are soil fungi and have a worldwide distribution. Some of them are plant pathogens, causing root and stem rot, vascular wilt or fruit rot. Several species have emerged as important opportunistic pathogens of humans causing hyalohyphomycosis (especially in burn victims and bone marrow transplant patients), mycotic keratitis and onychomycosis. Other species cause storage rot, and they are an important mycotoxin producers (Guarro 2013).

\section{MATERIAL AND METHODS}

Isolates of fungal cultures were obtained from the wood of trees in region of Moravia and one locality in Slovakia. Wood samples were sampled in orchards close to Valtice $(48.7406917 \mathrm{~N}, 16.7549906 \mathrm{E})$, Hlohovec (48.7739869N, 16.7623000E), Prostějov (49.4718783N, $17.1118397 \mathrm{E})$, and Znojmo-Hnízdo (48.7721919N, 16.1325519E).

One sample of sweet cherry was collected in Myjava - Slovakia (48.7524600N, 17.5661900E). The origin and number of explored trees is recorded in Table 1. For the analysis of cherry trees, apricots and plums with symptoms of water stress or nutrient lack including yellow leaves, dried shoots or dead branches were selected. From each tree upper, middle and lower segments of shoots, branches or trunks segments of wood were taken. These segments have been debarked, washed in distilled water and one minute surface disinfected in $2 \%$ sodium-hypochlorite solution and washed twice in sterile distilled water. Small pieces of symptomatic wood were placed on malt extract agar (MEA, Sigma Aldrich, St. Louis, Mossouri, USA) plates enriched by $0.5 \mathrm{~g} \mathrm{l}^{-1}$ streptomycin sulphate (Biosynth, Staad, Switzerland). The plates were stored in the dark from 10 to 20 days at $25^{\circ} \mathrm{C}$. For obtaining of the pure isolates, fungal mycelia were transferred on potato glucose agar (PGA, Sigma Aldrich) and placed into the same conditions. Before isolation of DNA a single hyphal tip isolates were prepared from each culture.

\section{DNA extraction}

Total DNA of cultured samples was extracted by NucleoSpin Tissue kit (Macherey-Nagel, Düren, Germany) according to manufacturer's instructions. We used $20 \mathrm{mg}$ of fungal culture collected from the PGA plates for DNA isolation.

\section{PCR for ITS amplification and sequencing}

The extracted DNA was amplified in the total volume of $20.8 \mu \mathrm{l}$. The reaction mix for PCR consisted of $10.5 \mu \mathrm{l}$ of water (HPLC purity), $4 \mu$ of $5 \times$ Colorless GoTaq Flexi Buffer for polymerase (Promega, Madison, USA), $1.2 \mu \mathrm{l}$ of $25 \mathrm{mM} \mathrm{MgC12}$ (Promega, Madison, USA), $0.2 \mu \mathrm{l}$ of $10 \mu \mathrm{M}$ dNTP mixture (Invitek, Berlin, Germany), $0.2 \mu$ of GoTaq G2 Flexi DNA polymerase $(5 \mathrm{U} / \mu \mathrm{l})$ (Promega, Madison, USA), $1 \mu \mathrm{l}$ of both primers $(10 \mu \mathrm{M})$ ITS3 and ITS4 (White et al. 1990), $0.7 \mu \mathrm{l}$ of Flexi $5 \times$ Green GoTaq Flexi Buffer (Promega, Madison, USA) and $2 \mu \mathrm{l}$ of DNA template.

The PCR was carried out as follows. After an initial denaturation for $3 \mathrm{~min}$ at $95^{\circ} \mathrm{C}$, the amplification was performed within 30 cycles of 2 min denaturation at $95{ }^{\circ} \mathrm{C}, 25 \mathrm{sec}$ of primer annealing at $50^{\circ} \mathrm{C}$ and $2 \mathrm{~min}$ at $72{ }^{\circ} \mathrm{C}$ for extension, followed by the final step at $72{ }^{\circ} \mathrm{C}$ for $5 \mathrm{~min}$.

PCR fragments were separated on 1.5\% agarose gel, stained by GelRed (Biotium, Hayward, USA) and visualized under UV light. Blank and negative controls were included in each test.

The PCR products corresponding to the size of approx. $330 \mathrm{bp}$ for ITS (depending on fungal species) were sequenced as described by Eichmeier et al. (2010).

Summarization of fungi detected in the trunks of stone fruit trees in the region of Moravia and Myjava (Slovakia)

\begin{tabular}{|c|c|c|c|c|c|}
\hline \multirow[b]{2}{*}{ Pathogen } & \multicolumn{5}{|c|}{ Host/Locality/number of trees } \\
\hline & $\begin{array}{c}\text { Sweet cherry/ } \\
\text { Znojmo-Hnízdo/ } \\
1 \text { tree }\end{array}$ & $\begin{array}{c}\text { Sweet cherry/ } \\
\text { Myjava/ } \\
1 \text { tree } \\
\end{array}$ & $\begin{array}{c}\text { Plum/ } \\
\text { Hlohovec/ } \\
3 \text { trees } \\
\end{array}$ & $\begin{array}{c}\text { Plum/ } \\
\text { Prostejov/ } \\
2 \text { trees } \\
\end{array}$ & $\begin{array}{c}\text { Apricot/ } \\
\text { Valtice/ } \\
4 \text { trees }\end{array}$ \\
\hline Irpex lacteus & & & & & present \\
\hline Fomes fomentarius & & & & & present \\
\hline Calosphaeria pulchella* & & & present & & present \\
\hline Cytospora leucostoma* & & present & present & & \\
\hline Phellinus tuberculosus & & & present & & \\
\hline Stereum hirsutum & & & present & & \\
\hline Neofabrea corticola & & & & & present \\
\hline Collophora sp.* & present & & present & & \\
\hline Pithomyces chartarum & & & & present & \\
\hline Aureobasidium pullulans & & & & present & \\
\hline Fusarium sp. & & & present & & \\
\hline
\end{tabular}

Note: all fungi were determined based on BlastN/NCBI, the minimal identity per ITS2 length was $95 \%$, with e-value $<10^{-5}$, * stone fruit trunk pathogens presented before (Scorza and Pusey 1984, Damm et al. 2008, Gramaje et al. 2012) 
Sequencing was carried out using ITS4 (White et al. 1990). The ITS amplification in case of Neofabraea corticola produced amplicon that was impossible to sequence for many times, maybe because of some contamination in DNA. We used amplification of beta tubulin gene (Petit and Gubler 2005) and we sequence it with reverse primer.

The obtained nucleotide sequences were analysed using CLC Main Workbench 5.0 (CLC bio, Aarhus, Denmark).

\section{RESULTS AND DISCUSSION}

Fungal mycelia were grown from the symptomatic wood of $P$. avium (2 trees), P. domestica (5 trees) and
P. armeniaca (4 trees). Detected species were summarized in the Table 1.

Figure 1 - Phylogenetic analysis of ITS2 (White et al. 1990) sequences by Maximum Likelihood method based on the Tamura-Nei model (Tamura and Nei 1993). There are included fungi detected in South Moravia and Slovakia (Myjava) in the trunks of stone fruits. The isolates in the higher black box belong to Ascomycota and the lower black box contains Basidiomycota. Cladogram was constructed with MEGA 7 (Kumar et al. 2016), Muscle alignment (Edgar 2004) and UPGMB clustering method were used. The name of locality of sampling is included behind the names of fungi. All nodes supporting a threshold of 24, are indicated. Scale bar represents units in nucleotide substitutions per site.

Figure 1: Phylogenetic analysis of the fungi detected in the trunk of stone fruits

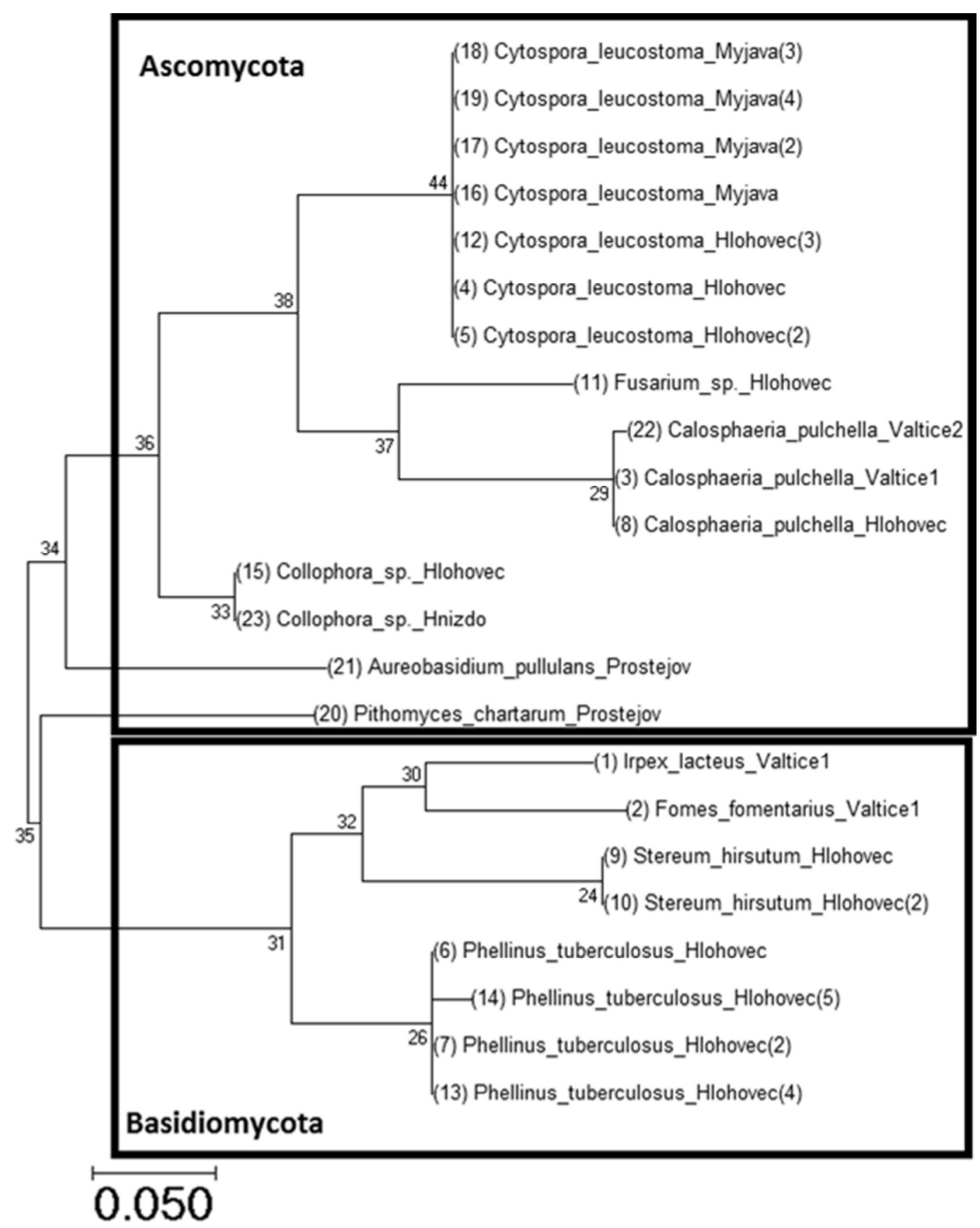


Figure 1 shows the phylogenetic relationship between detected fungi. The results of blast $\mathrm{N}$ analysis (NCBI) were based on percent identity as described in legend for Table 1.

The phylogenetic tree excludes wrong results via clustering of the same fungi genera/species together. Moreover, there is clearly showed how many members of Ascomycota and Basidiomycota were detected. Aureobasidium pullulans and Pithomyces chartarum (both from Prostejov) create an imaginary border among two Dikarya groups. However, these fungi are not established as trunk pathogens. This study describes detection of Calosphaeria pulchella in the wood of apricot and plum trees isolated from sectorial wood necrosis. This is in compliance that $C$. pulchella was isolated from sectorial wood necrosis associated with swollen bark and gum exudates and diseased branches and reported as an agent of canker and branch dieback of sweet cherry in Spain (Berbegal et al. 2014). This fungus was also described as the main species isolated from sweet cherry in California. The pathogenicity of C. pulchella in sweet cherry was confirmed following field inoculations of 2-years-old to 3-years-old branches (Trouillas et al. 2012). This pathogen is also associated with almond and cherry die back and decline in Iran. Results of pathogenicity assay using an excised shoot method showed that $C$. pulchella is highly pathogenic on almond (Arzanlou and Dokhanchi 2013).

Cytospora leucostoma was detected from the samples obtained from sweet cherry trees and plum trees. C. leucostoma causes xylem dysfunction and is was isolated from lesions on the infected twigs of host plants (Pokharel and Reighhard 2013). This could be the reason why we observed symptoms on the plants like yellowing of leaves, drought branches and dying trees in general. This fungus is the most important economic problem for stone fruit plantations in western Colorado. It does not have effective management options available including chemicals (Pokharel and Reighhard 2013). At the present time, C. leucostoma cannot be effectively controlled in China. It is a destructive disease of apples and mainly harms the trunk and main branches leading to cortical rot followed by branch and the tree death (Chen et al. 2016). Cytospora species is also described as pathogen of poplars and willows in China (Wang et al. 2015), grapevine in North America (Lawrence 2016) and hazelnuts in Italy (Lamichhane 2014).

As described above species of Collophora have been reported in a list of fungal trunk pathogens isolated from Prunus sp. Isolate in this study was obtained from sweet cherry and plum tree. Arzanlou et al. (2016) isolated Collophora with high frequency from wood samples showed internal necrosis and brown to black vascular streaking in Iranian almond trees. In Spain Collophora hispanica has been isolated and based on phytopathogenicity test was considered as serious trunk pathogen of almond trees (Olmo et al. 2015). Damm et al. (2010) detected and described five species of Collophora as trunk pathogen of apricots, peaches and plums.

There is a second group of fungi isolated from the wood of stone fruits in Czech Republic. These species have wide spectrum of hosts and some of them are defined as parasitic and/or saprobic. However, these species are not established as an important trunk pathogens of stone fruits. Aureobasidium pullulans is worldwide spread fungus and there is no known connection between trunk disease and its presence. Also Fusarium is very extensive genus including hundreds of species and it is also not described as trunk pathogen. F. laterinum is used as biological control agent to provide long-term protection of pruning wounds against trunk diseases (Kotze et al. 2011). Although a canker diseases and bark canker of Pomaceae caused by Neofabarea corticola were reported (Jorgensen 1930, Ciferri et al. 1960, Pešicová 2010). In many cases presence of these species is connected with weakened health of trees.

Fomes fomentarius is one of the principal decay fungi on beech in some parts of continental Europe and this niche also often occupied by Stereum sp. We isolated the fungus from softer wood of very dying apricots in locality Valtice. F. fomentarius has been recorded from a wide range of angiospermous hosts; e.g. beech, birch, oak, poplar, maple and more rarely alder and hornbeam (Schwarze 1994). Reports on Phellinus have been published as studies on wood-decayig fungi. Nevertheless as described above Phellinus tuberculocus is described as causal agent of symptoms on stone fruits. We detected it in the wood of plums. Irpex lacteus is characterized as white rot fungus on decayed wood (Novotný et al. 2000, Svobodová et al. 2008) and we detected it in the same plant as F. fomentarius, very dying apricots. Pithomyces chartarum is wide spread fungus associated with leaf spots on poaceae family (Tóth et al. 2007, Gonçalves et al. 2013). Aureobasidium pullulans is worldwide spread fungus and there is no described connection between trunk disease and its presence. Fusarium sp. is very extensive genus including hundreds of species. The plums infected by $A$. pullulans and $P$. chartarum from Prostejov were infected by Candidatus Phytoplasma prunorum (data not shown). So the reason of symptoms of proliferation and decaying could be the phytoplasma infection.

We could conclude that nowadays stone fruit growers in the Czech Republic have their economic problems caused probably by the trunk pathogens. This should be confirmed by wider study. Except of not so serious trunk fungi as Aureobasidium pullulans or Fusarium sp. we detected also very dangerous and important trunk pathogens as Cytospora leucostoma, Calosphaeria pulchella and Collophora $\mathrm{sp}$. in the wood of dying stone fruit trees. Moreover, many of them were phytoplasma free (data not showed).

This is a pilot study of fungal trunk pathogens of stone fruits in the Czech Republic, the study will be extended.

\section{ACKNOWLEDGEMENTS}

This research would not have been possible without funding provided by the Ministry of Education of the Czech Republic - Project No. LD14051, which is supported by the COST action FA1303 „, Sustainable control of grapevine trunk diseases. "We would like also to thank to Josep Armengol for his advices regarding the workflow of fungal isolations. 


\section{REFERENCES}

Arzanlou, M.-Dokhanchi, H. (2013): Calosphaeria canker of almond caused by Calosphaeria pulchella in Iran. Archives of Phytopathology and Plant Protection. 46. 2: 215-226.

Arzanlou, M.-Ghasemi, S.-Baradaran, B. M. (2016): Collophora hispanica, a New Pathogen and Potential Threat to the Almond Industry in Iran. Journal of Phytopathology. 164. 10: 833-839.

Becha, T. (2013): Historický vývoj ovocnictví na České republiky. Lednice, Bakalářská práce. Mendelova Univerzita v Brně. Vedoucí práce Tomáš Nečas.

Berbegal, M.-García-Jiménez, J.-Armengol, J. (2014): First Report of Calosphaeria pulchella Causing Canker and Branch Dieback of Sweet Cherry Trees in Spain. Plant Disease. 98. 7: 1008.

Bertsch, C.-Ramírez-Suero, M.-Magnin-Robert, M.-Larignon, P.Chong, J.-Abou-Mansour, E.-Fontaine, F. (2013): Grapevine trunk diseases: complex and still poorly understood. Plant Pathology. 62. 2: 243-265.

Binion, D. E.-Stephenson, S. L.-Roody, W. C.-Burdsall, H. H. Jr.Vasilyeva, L. N.-Miller, O. K. Jr. (2008): Macrofungi of Oak. Morgantown - WV. West Virginia University Press. 467.

Buchrová, I. (2015): Situační a výhledová zpráva. Praha: Ministerstvo zemědělství České republiky. (2016. 11. 24.)

Carbone, I.-Kohn, L. M. (1999): A method for designing primer sets for speciation studies in filamentous ascomycetes. Mycologia 553-556.

Carlucci, A.-Lops, F.-Cibelli, F.-Raimondo, M. L. (2014): Phaeoacremonium species associated with olive wilt and decline in southern Italy. European Journal of Plant Pathology. 141: 717-729.

Carlucci, A.-Raimondo, M. L.-Cibelli, F.-Phillips, J. L.-Lops, F. (2013): Pleurostomophora richardsiae, Neofusicoccum parvum and Phaeoacremonium aleophilum associated with a decline of olives in southern Italy. Phytopathologia Mediterranea. 52: 517-527.

Chen, C.-Li, B. H.-Dong, X. L.-Wang, C. X.-Lian, S.-Liang, W. X. (2016): Effects of Temperature, Humidity, and Wound Age on Valsa mali Infection of Apple Shoot Pruning Wounds. Plant Disease. 100. 12: 2394-2401.

Ciferri, R.-Corte, A.-Rui, D. (1960): Bark canker of Pomaceae in Italy. Atti Ist. Bot. Univ. Pavia. 5. 17: 329-336.

Cloete, M.-Fourie, P. H.-Damm, U.-Crous, P. W.-Mostert, L. (2011): Fungi associated with die-back symptoms of apple and pear trees, a possible inoculum source of grapevine trunk disease pathogens. Phytopathologia Mediterranea. 50: S176-S190.

Da Cunha, K. C.-Sutton, D. A.-Gené, J.-Cano, J.-Capilla, J.Madrid, H.-Decock, C.-Wiederhold, N. P.-Guarro, J. (2014): Pithomyces species (Montagnulaceae) from clinical specimens: identification and antifungal susceptibility profiles. Medical Mycology. myu044.

Damm, U.-Crous, P. W.-Fourie, P. H. A (2008): Fissitunicate ascus mechanism in the Calosphaeriaceae, and novel species of Jattaea and Calosphaeria on Prunus wood. Persoonia - Molecular Phylogeny and Evolution of Fungi. 20. 1: 39-52.

Damm, U.-Fourie, P. H.-Crous, P. W. (2010): Coniochaeta (Lecythophora), Collophora gen. nov. and Phaeomoniella species associated with wood necroses of Prunus trees. Persoonia - Molecular Phylogeny and Evolution of Fungi. 24. 1: 60-80.

Damm, U.-Mostert, L.-Crous, P. W.-Fourie, P. H. (2008): Novel Phaeoacremonium species associated with necrotic wood of Prunus trees. Persoonia. 20: 87-102.

Dingley Joan, M. (1962): Pithomyces chartarum, its occurrence morphology, and taxonomy. New Zealand Journal of Agricultural Research. 5. 1-2: 49-61.
Edgar, R. C. (2004): MUSCLE: multiple sequence alignment with high accuracy and high throughput. Nucleic Acids Research. 32 5: $1792-1797$

Eichmeier, A.-Baranek, M.-Pidra, M. (2010): Analysis of genetic diversity and phylogeny of partial coat protein domain in Czech and Italian GFLV isolates. Plant Protection Science. 46. 4: $145-148$

Fischer, M. (1996): On the species complexes within Phellinus: Fomitiporia revisited. Mycological Research. 100. 12: 1459-1467.

Ghobad-Nejhad, M.-Dai, Y. C. (2007): The genus Phellinus sp. (Basidiomycota) in Iran. Mycotaxon. 101: 201-222.

Glaeser, J. A.-Smith, K. T. (2010): Decay fungi of oaks and associated hardwoods for western arborists. Western Arborist. Winter. 2010: 32-46.

Gonçalves, R. M.-Figueiredo, J. E. F.-Pedro, E. S.--Meirelles, W. F.-Leite, R. P.-Sauer, A. V.-Paccola-Meirelles, L. D. (2013): Etiology of Phaeosphaeria leaf spot disease of maize. Journal of Plant Pathology. 559-569.

Gramaje, D.-Agustí-Brisach, C.-Pérez-Sierra, A.-Moralejo, E.Olmo, D.-Mostert, L.-Damm, U.-Armengol, J. (2012): Fungal trunk pathogens associated with wood decay of almond trees on Mallorca (Spain): Persoonia. 28. 1: 1-13.

Gramaje, D.-Armengol, J.-García-Jiménez, J.-Aroca, Á.-Raposo, R. (2010): Evaluation of the grapevine nursery propagation process as a source of Phaeoacremonium spp. and Phaeomoniella chlamydospora and occurrence of trunk disease pathogens in rootstock mother vines in Spain. European Journal of Plant Pathology. 126. 2: 165-174.

Guarro, J. (2013): Fusariosis, a complex infection caused by a high diversity of fungal species refractory to treatment. European Journal of Clinical Microbiology \& Infectious Diseases. 32: 1491-1500.

Hampson, M. C.-Sinclair, W. A. (1973): Xylem dysfunction in peach caused by Cytospora leucostoma. Phytopathology. 63: 676-681.

He, J. B.-Feng, T.-Zhang, S.-Dong, Z. J.-Li, Z. H.-Zhu, H. J.-Liu, J. K. (2014): Seven New Drimane - Type Sesquiterpenoids from Cultures of Fungus Phellinus tuberculosus. Natural Products and Bioprospecting. 4. 1: 21-25.

Inderbitzin, P.-Bostock, R. M.-Trouillas, F. P.-Michailides, T. J. (2010): A six locus phylogeny reveals high species diversity in Botryosphaeriaceae from California almond. Mycologia. 102: 1350-1368.

Jorgensen, C. A. (1930): Bark canker on Apples and Pears caused by Neofabraea corticola (Edgert.) CAJ n. sp. et n. comb. Tidsskrift for Planteavl. 36. 5: 800-811.

Kotze, C.-Van Niekerk, J.-Halleen, F.-Mostert, L.-Fourie, P. (2011) Evaluation of biocontrol agents for grapevine pruning wound protection against trunk pathogen infection. Phytopathologia Mediterranea. 50. 4: 247-263.

Kumar, S.-Stecher, G.-Tamura, K. (2016): MEGA7: Molecular Evolutionary Genetics Analysis version 7.0 for bigger datasets. Molecular Biology and Evolution. msw054.

Lamichhane, J. R.-Fabi, A.-Varvaro, L. (2014): Summer heat and low soil organic matter influence severity of hazelnut Cytospora canker. Phytopathology. 104. 4: 387-395.

Lawrence, D. P.-Travadon, R.-Pouzoulet, J.-Rolshausen, P. E.Wilcox, W. F.-Baumgartner, K. (2016): Characterization of Cytospora isolates from wood cankers of declining grapevine in North America, with the descriptions of two new Cytospora species. Plant Pathology. 
Nečas,T.-Ondrášek, I.-Krška, B. (2014): 'Candidatus Phytoplasma prunorum' - a pathogen spreading uncontrollably in apricot orchards in the Czech Republic. XXIX. International Horticultural Congress on Horticulture: Sustaining Lives, Livelihoods and Landscapes (IHC2014): 1105: 131-136.

Novotný, Č.-Erbanova, P.-Cajthaml, T.-Rothschild, N.-Dosoretz, C.-Šašek, V. (2000): Irpex lacteus, a white rot fungus applicable to water and soil bioremediation. Applied Microbiology and Biotechnology. 54. 6: 850-853.

Olmo, D.-Armengol, J.-León, M.-Gramaje, D. (2015): Pathogenicity testing of lesser-known fungal trunk pathogens associated with wood decay of almond trees. European Journal of Plant Pathology. 143. 3: 607-611.

Ovocné sady (Strukturální šetření) 2012: Www.czso.cz. Praha, 2013 (cit. 2016-11-17). http://www.ovocnarska-unie.cz/pdf/cenzus sady_2012_csu.pdf

Pešicová, K. (2010): Houby ovocných dřevin se zvláštním zřetelem k rodu Neofabraea. Praha, Bakalářská práce. Univerzita Karlova v Praze. Vedoucí práce RNDr. David Novotný PhD.

Petit, E.-Gubler, W. D. (2005): Characterization of Cylindrocarpon species, the cause of black foot disease of grapevine in California. Plant Disease. 89. 10: 1051-1059.

Pokharel, R. R.-Reighard, G. L. (2013): Evaluation of rootstock effect on tolerance to iron chlorosis and Cytospora canker in peaches. VIII. International Peach Symposium. 1084: 159-164.

Polák, J.-Boleloucký, P.-Glasa, M.-Hnízdil, M.-Jarošová, J.Komínek, P.-Krška, B.-Kumar, J.-Kurka, M.-Ludvík, M.Ondrášek, I.-Polák, J.-Salava, J. (2010): Šarka peckovin současný stav problematiky v České republice a v Evropě. Výzkumný ústav rostlinné výroby v.v.i.

Schwarze, F. (1994): Wood rotting fungi: Fomes fomentarius (L.: Fr.) Fr. Mycologist. Volume 8 Part 1.

Scorza, R.-Pusey, P. L. (1984): A wound-freezing inoculation technique for evaluating resistence to Cytospora leucostoma in young peach trees. Phytopathology. 74. 5: 569-572.

Svobodová, K.-Majcherczyk, A.-Novotný, Č.-Kües, U. (2008): Implication of mycelium-associated laccase from Irpex lacteus in the decolorization of synthetic dyes. Bioresource Technology. 99. 3: 463-471.
Tamura, K.-Nei, M. (1993): Estimation of the number of nucleotide substitutions in the control region of mitochondrial DNA in humans and chimpanzees. Molecular Biology and Evolution. 10. 3: $512-526$

Tóth, B.-Csősz, M.-Dijksterhuis, J.-Frisvad, J. C.-Varga, J. (2007): Pithomyces chartarum as a pathogen of wheat. Journal of Plant Pathology. 405-408.

Trouillas, F. P.-Lorber, J. D.-Peduto, F. Grant, J.-Coates, W. W.Anderson, K. K. -Caprile, J. -Gubler, W. D. (2010): First report of Calosphaeria pulchella associated with branch dieback of sweet cherry trees in California. Plant Disease. 94. 9: 1167-1167.

Trouillas, F.-Peduto, J. D.--Lorber, M. R.-Sosnowski, J.-Grant, W. W.-Coates, K. K.-Anderson, J.-Caprile, W. D. (2012): Calosphaeria canker of sweet cherry caused by Calosphaeria pulchella in California and South Australia. Plant Disease. 96. 5: 648-658.

Úrbez-Torres, J. R.-Peduto, F.-Vossen, P. M.-Krueger, W. H.Gubler, W. D. (2013): Olive twig and branch dieback: etiology, incidence, and distribution in California. Plant Disease. 97: 231-244.

Verkley, G. J. M. (1999): A monograph of the genus Pezicula and its anamorphs. Studies in Mycology. 44: 180.

Wang, Y. L.-Lu, Q.-Decock, C.-Li, Y. X.-Zhang, X. Y. (2015): Cytospora species from Populus and Salix in China with C. davidiana sp. nov. Fungal Biology. 119. 5: 420-432.

White, T. J.-Bruns, T.-Lee, S. J. W. T.-Taylor, J. W. (1990): Amplification and direct sequencing of fungal ribosomal RNA genes for phylogenetics. PCR protocols: a guide to methods and applications. 18. 1:315-322.

Zalar, P.-Gostinčar, C.-De Hoog, G. S.-Uršič, V.-Sudhadham, M.Gunde-Cimerman, N. (2008): Redefinition of Aureobasidium pullulans and its varieties. Studies in Mycology. 61: 21-38.

Žežlina, I.-Rot, M.-Kač, M.-Trdan, S. (2016): Causal Agents of Stone Fruit Diseases in Slovenia and the Potential for Diminishing Their Economic Impact - a Review. Plant Protect. Sci. 52: 149-157. 
